\title{
Soil functions and ecosystem services in conventional, conservation, and integrated agricultural systems. A review
}

\author{
Ilan $\mathrm{Stavi}^{1} \cdot{\text { Golan } \text { Bel }^{2} \cdot \text { Eli Zaady }}^{3}$
}

Accepted: 4 April 2016/Published online: 26 April 2016

(C) INRA and Springer-Verlag France 2016

\begin{abstract}
Soil tillage, crop residue management, nutrient management, and pest management are among the core farming practices. Each of these practices impacts a range of soil functions and ecosystem services, including water availability for crops, weed control, insect and pathogen control, soil quality and functioning, soil erosion control, soil organic carbon pool, environmental pollution control, greenhouse gas refuse, and crop yield productivity. In this study, we reviewed relevant bibliography and then developed a simple conceptual model, in which these soil functions and ecosystem services were scored and compared between conventional, conservation, and integrated agricultural systems. Using this conceptual model revealed that the overall agro-environmental score, excluding crop yield productivity, is largest for conservation systems $(71.9 \%)$, intermediate for integrated systems $(68.8 \%)$, and the smallest for conventional systems $(52.1 \%)$. At the same time, the crop yield productivity score is largest for integrated systems $(83.3 \%)$, intermediate for conventional systems $(66.7 \%)$, and the smallest for conservation systems $(58.3 \%)$. This study shows the potential of moderate-intensity and integrated farming systems in carrying on global food security while adequately sustaining environmental quality and ecosystem services.
\end{abstract}

Ilan Stavi

istavi@adssc.org; istavi@yahoo.com

Dead Sea \& Arava Science Center, Yotvata 88820, Israel

2 Department of Solar Energy and Environmental Physics, Jacob Blaustein Institutes for Desert Research, Ben-Gurion University of the Negev, Sede Boqer Campus 8499000, Sede Boqer, Israel

3 Department of Natural Resources, Agricultural Research Organization, Gilat Research Center 85280, Gilat, Israel
Keywords Agricultural intensity · Cropping systems · Ecological impact assessment · Environmental health . Greenhouse gas emissions · Land degradation and desertification $\cdot$ Low-input agriculture $\cdot$ Sustainable farming

\section{Contents}

1 Introduction

2 Literature analysis

3 Tillage methods

4 Crop residue management

5 Nutrient management

6 Pest management

7 Data integration and general discussion

8 Conclusions

Acknowledgments

References

\section{Introduction}

Agricultural intensification has been perceived as vital for meeting global food demand. However, over time, awareness of the adverse environmental impact caused by conventional cropping systems has grown. Nowadays, there is broad agreement that conventional cropping systems have adverse environmental impacts, with the potential of risking natural ecosystems and human health over both the short and long terms (Duru et al. 2015). Some of the main risks are water source depletion, on-site and off-site soil and water resource contamination, air pollution and greenhouse gas emissions, soil organic carbon depletion, erosion of soil fertile layers by wind and water, and soil salinization (Horrigan et al. 2002). Particularly, conventional cropping systems have led to land 
degradation, putting global food security at risk (Hurni et al. 2015). In addition to food, the production of vegetative fiber as feed for the livestock sector has an enormous environmental footprint, further exacerbating pressures on natural resources (Jankielsohn 2015). Furthermore, the increasing reach of the bio-energy sector has led to the conversion of extensive croplands from food and feed production to bioenergy cropping (Tilman et al. 2009). Simultaneously, the increase in global human populations has resulted in a growing demand for food, feed, and bioenergy cropping, accelerating additional land-use change from natural lands to croplands (Alexander et al. 2015; Zdruli et al. 2014). It has been shown that degradation of natural resources adversely affects potential agronomic productivity (Agrawal 2005; Vadez et al. 2012), forming a positive feedback between agricultural production and environmental quality, which further weaken each other.

Since the late twentieth century, conservation agriculture has become a growing sector in both developed and developing countries, aimed at minimizing environmental footprints and sustaining natural environments and resources (Liu 1999). However, the concept of full conservation and low-impact practices can impose serious limitations in terms of soil quality and fertility and agroecosystem functioning and health. For example, conservation tillage may increase water deficiency for crops in drought years (Vyn et al. 2013), entire retention of crop residue might boost pest infestation (Cork et al. 2005), organic nutrient management can augment risk of off-site water source contamination (Flores et al. 2012), and nonchemical pest management presents high risk of crop loss due to pest infestation (Pretty and Bharucha 2015).

Since prevailing farming paradigms perceive high crop yields and low environmental impact as being in conflict with one another (Zhang et al. 2012), it is of crucial importance to define an environmentally sound range of agronomic activities, of which a certain extent of intensity would be considered tolerable (Fig. 1). Particularly, in this study, moderate-intensity and integrated agronomic systems are discussed in detail, with regard to both the overall environmental footprint of croplands and their capacity to sustain crop yield productivity. Indeed, over time, moderateintensity and integrated agricultural systems, which aim to maintain high yields while sustaining natural environments and resources, have attracted increasing attention. According to this approach, natural resources should be used as a means to generate quantitatively and qualitatively fair crops, while sustaining environmental quality for the sake of next generations (Chen et al. 2011). Yet, despite these trends, actual implementation of moderate-intensity and integrated agricultural systems is still far below its potential. In this study, moderate-intensity and integrated paradigms refer to combinations of certain conventional and conservation concepts with regard to the core farming practices of tillage

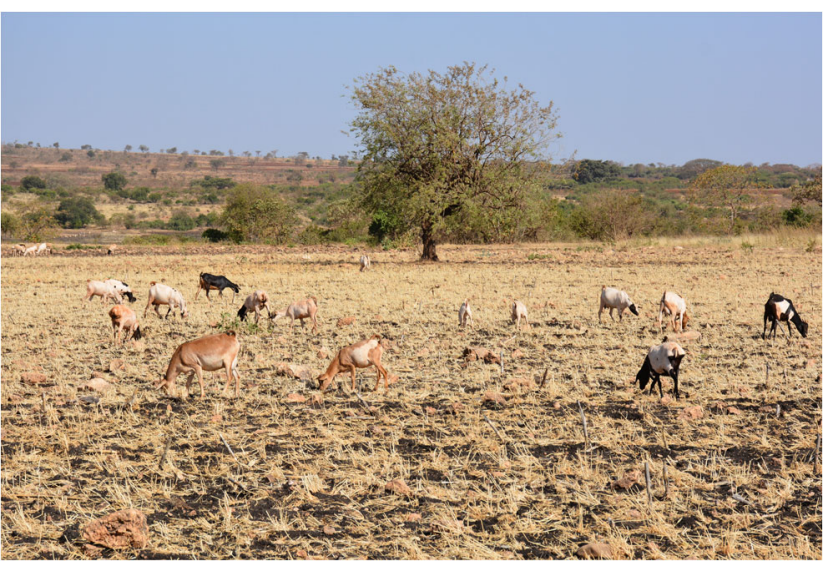

Fig. 1 Moderate stubble grazing in a post-harvest wheat field by a flock of goats. This management practice demonstrates a moderate-intensity and integrated agricultural system. Photo taken by Allan Degen in the semi-arid Libin region in southern Ethiopia

methods, crop residue management, nutrient management, and pest management. Respectively, we refer, in this review study, to the integrated practices of moderate tillage, moderate on-site retention of crop residue, integrated nutrient management, and integrated pest management. Each of these lies between two extremes of higher and lower intensity. We considered both on-site impacts that directly affect the agroecosystem's features and potential productive capacity, as well as the off-site impacts that are more relevant to the quality of the wider environment and which could only indirectly affect agronomic productivity.

Ecosystem services include the direct and indirect benefits and contributions of ecosystems to human well-being. These include (1) provisioning services, such as food, feed, fiber, and fresh water; (2) regulating services, such as flood and disease control, and climate regulation; (3) supporting services, such as soil formation, water and nutrient cycling, the production of atmospheric oxygen, and provisioning of habitats; and (4) cultural services, such as a range of spiritual, recreational, and aesthetic benefits (Duru et al. 2015). Among other definitions of soil functions is the provision of an adequate living environment for the soil food web, vegetation, and humans (Haslmayr et al. 2016). Soil functions can be classified as provisioning, regulating, or supporting services, while agricultural activities directly or indirectly impact all types of ecosystem services. Particularly, intensification of agriculture has led to the considerable depletion of a range of ecosystem services (Williams and Hedlund 2014).

The objective of this review study was to assess - through the use of a simple conceptual model - the related agronomic features and environmental impacts of moderate-intensity and integrated cropping systems, while comparing them to those of conventional systems on the one hand and those of conservation systems on the other. The rationale behind this objective was to fill the gap in comparable knowledge among these 
three types of agricultural systems. While doing that, main soil functions and ecosystem services were discussed, and their relative impact was calculated by using a simple scoring procedure. The paper focuses on annual field crops and excludes perennial crops.

\section{Literature analysis}

The soil functions and ecosystem services discussed in this study include the following nine items: (i) water availability for crops (as determined by the soil-water dynamics); (ii) weed control (as determined by the applied agro-techniques); (iii) insect and pathogen control (also, as determined by the applied techniques); (iv) soil quality and functioning (including physical, chemical, and biological components); (v) soil erosion control (including rill, inter-rill, and gully erosion); (vi) soil organic carbon pool (the total organic carbon pool, without relating to specific functional fractions); (vii) environmental pollution control (including preventing contamination of water, soil, and air resources); (viii) greenhouse gas refuse (including carbon dioxide, nitrous oxide, and methane); and (ix) crop yield productivity (including both vegetative and reproductive plant material). Additional functions/services could be considered relevant for this kind of study; for example, nutrient-use efficiency is an important agronomic service, but a decision was taken to not include it directly in the model. This decision was taken in order to negate redundancy and because sub-aspects of nutrient-use efficiency are embedded in other services, including soil quality, soil erosion control, environmental pollution control, and greenhouse gas refuse, all of which are related to, or considered regulators of, soil nutrient pool. Similarly, sustaining biodiversity in agricultural systems is also an important agro-environmental service but was not directly included in the model. This was because subaspects of this service are either directly or indirectly included in other services, including weed control, insect and pathogen control, and soil quality and functioning.

A literature review was undertaken focusing on the impact of each of the following core farming practices: (1) tillage methods, (2) crop residue management, (3) nutrient management, and (4) pest management on the nine above-mentioned soil functions and ecosystem services. This included three levels of intensity for each of these services. In this way, the high intensity level was discussed in relation to conventional tillage, full removal of crop residue, chemical nutrient management, and chemical pest management. Medium intensity was discussed in relation to moderate tillage, moderate removal of crop residue, integrated nutrient management, and integrated pest management. Finally, low intensity was discussed in terms of no-till, no removal of crop residue, organic nutrient management, and organic pest management. It is acknowledged that this general structure, which distinguishes between two extremes and one medium case for each of the four farming practices, could be considered an oversimplification of a much more complex reality. Also, numerous combinations with other, complementary practices, such as crop rotation, ley farming (fallowing), inter-cropping, cover-cropping, etc., exist, making the abstraction into a simple synthesized framework rather difficult. Moreover, we have no evidence that different scoring methods would yield the same results. Yet, this simplified structure of the conceptual model was utilized in order to ease the abstracting and analysis of data and to enable an assessment of the overall agro-environmental impact of these core farming practices.

At the next stage, impacts were rated according to three score levels: low (a rank of 1), medium (a rank of 2), and high (a rank of 3). This allowed us to separately calculate the scores for each of the nine soil functions/ecosystem services and according to a combination of agronomic practice and level of intensity. The ranking was based on a graduated scale, of which the higher the score, the better the agro-environmental ranking. A rank of 1 or 3 was given only for a direct and clear effect. A rank of 2 was given for a medium effect, as well as in the event of an indirect effect, not clear effect, a possible bimodal effect, or irrelevance. In each of the following sections-Sects. 3, 4, 5, and 6, for the practices of tillage methods, crop residue management, nutrient management, and pest management, respectively - the effects of each of the conventional, conservation, and moderate/integrated systems on each of the above nine functions/services were discussed according to the three levels of intensity and then ranked. In these sections, the given score was indicated throughout the text by the marks "[1]," "[2]," or "[3]" for the low, medium, and high agro-environmental ranks, respectively. For ease of presentation, a spider chart was created for each of the four farming practices, visually presenting their impacts on each of the nine functions/services, and according to level of intensity. The crop yield was analyzed separately from the other eight functions/services. The rationale for this separation was to highlight this sole provisioning service, as opposed to the other eight regulating or supporting services.

Mathematically, we described the score of each of the eight functions/services as a variable $x_{i}^{j, k}$, where $i$ represents the function/service, $j$ represents the farming practice, and $k$ represents the intensity of that practice. $x_{i}^{j, k}$ takes the values $1 / 3$, $2 / 3$, and 1 for the marks [1], [2], and [3], respectively. Similarly, the crop yield score is defined for each combination of farming practice and intensity as $p^{j, k}$.

Subsequently, ranks of each of the eight functions/services (all excluding crop yield productivity) for each combination of agronomic practice and level of intensity were averaged, forming a single inclusive value per each combination. The average score for each combination was mathematically defined as $y^{j, k}=\frac{1}{8} \sum_{i=1}^{8} x_{i}^{j, k}$. Then, normalized values of the four 
farming practices (for all functions/services excluding crop yield productivity) were added together according to level of intensity, and their overall average was calculated. The score per intensity level is defined as $z^{k}=\frac{1}{4} \sum_{j=1}^{4} y^{j, k}$. Similarly, the average crop yield score for each intensity was calculated (by averaging the four farming practices) and is defined as $P^{k}=\frac{1}{4} \sum_{j=1}^{4} p^{j, k}$.

It is important to mention that giving a certain score for a function/service was based on impacts that are widely (though not always exclusively) accepted. It is agreed that this approach could contradict certain local conditions, temporary or transient circumstances, or extreme situations, which would yield modifications in some of the impacts and the resultant scores. Also, for ease of discussion and calculation, weight i.e., agronomic-environmental importance, for each of the nine functions/environmental services, as well as for each of the four farming practices, was assumed to be equal (1/9 and $1 / 4$, respectively). It is acknowledged that basing a differential, relative weight for each service and practice could have yielded somewhat different results. However, such a differential calculation could not have been implemented because of the lack of relevant knowledge at present. Despite these limitations, the importance of this study stems from it being the first to assess, under a whole and inclusive framework, the overall agro-environmental impact of conventional, conservation, and integrated farming systems.

\section{Tillage methods}

Tillage of croplands is a basic agronomic method, aimed at loosening upper soil layers and preparing seedbed for the subsequent crop. Tillage method effects on soil functions and ecosystem services are presented in Fig. 2.

Depending on the combination of climatic and pedogenic settings, conventional tillage has either a positive or negative effect on the soil moisture status and its availability for crops [2] (Kettler et al. 2000; Vetsch et al. 2007; Miller et al. 2012). At the same time, high tillage intensity has proven to be efficient in controlling the infestation of weeds [3] (Abdin et al. 2000; Lazauskas and Pilipavicius 2004; Gruber and Claupein 2009) and pests [3] (McLaughlin and Mineau 1995; Cabanillas et al. 1999; IARI 2012). Nevertheless, conventional tillage has a detrimental impact on the physical quality of soil [1] (Horrigan et al. 2002; Ji et al. 2015), with the subsequent increase in frequency and magnitude of erosional processes [1] and boost in oxidation of soil organic carbon [1] (Horrigan et al. 2002; Zdruli et al. 2014). Overall, conventional tillage has both positive and negative effects on environmental quality [2] but, due to the very high use of machinery

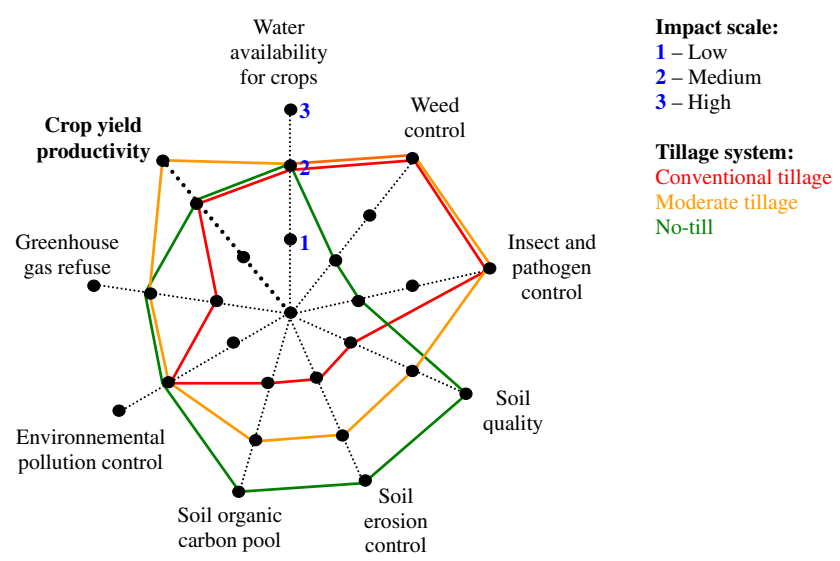

Fig. 2 Spider chart of tillage impact on soil functions and ecosystem services. Impacts are separately presented for the three levels of intensity of tillage, including conventional tillage, moderate tillage, and no-till. The major soil functions and ecosystem services are graded for each of the tillage intensities according to a scale of the following: 1 for low score, 2 for moderate score, and 3 for high score

in seedbed preparation, is defined as causing high greenhouse gas emissions, particularly of carbon dioxide [1] (Schneider and Smith 2009; Ho 2011). Despite potentially increasing crop yields in the short run, the overall degradation of geoecosystems often tends to limit crop productivity in the long run [2] (Wienhold and Weil 2006; Ji et al. 2015).

Conservation tillage methods have been developed to overcome the adverse agro-ecological impacts of conventional tillage. Of these methods, no-till has been widely accepted in conservation agriculture, negating any type of tillage. However, it was reported that the soil-water status under notill is highly dependent on climatic and other physical conditions [2] (Kennedy and Schillinger 2006; TerAvest et al. 2015). For example, it was reported that no-till may increase water availability for crops in average years but limits its availability in drought years (Nixon 2009). Moreover, no-till does not provide effective means for controlling infestation of weeds [1] (Abdin et al. 2000; Harker et al. 2013) or pests [1] (Cabanillas et al. 1999; IARI 2012). Still, the zero disturbance of the soil structure improves the physical quality of soil [3] (Ji et al. 2015), efficiently controls erosional processes [3], and augments carbon sequestration in soil [3] (Lal 2004; Stavi and Argaman 2014). Nevertheless, no-till has both positive and negative impacts on environmental quality [2] (Stavi and Argaman 2014). A specific example of adverse effect is the high risk of environmental pollution imposed by the excess use of herbicides and pesticides (Harker et al. 2013). Specifically, the lower need for farm machinery work in seedbed preparation, with the resultant lower fuel consumption and coupled with the generally smaller emissions of carbon dioxide from soil, decreases on-site greenhouse gas emissions. Yet, the high emissions related to manufacturing and transportation of herbicides and pesticides (Ho 2011) increase off-farm emissions, with the resultant positive and negative impacts on 
greenhouse gas emissions [2] (Lal 2004). Overall, no-till is defined with case-dependant and site-specific effects on crop yields [2] (e.g., Kettler et al. 2000; Vetsch et al. 2007; Nixon 2009).

Moderate tillage methods are those which combine some sort of cultivation in order to confront agronomic challenges imposed by either conventional tillage or no-till. Several types and procedures of moderate tillage methods have been developed, mitigating tillage intensity at either the spatial or the temporal level. For example, strip tillage, in which cultivation is restricted to the seeding/planting rows, while the inter-row spaces remain undisturbed (Vetsch et al. 2007). An example of the temporally moderate method is occasional tillage, in which cultivation is conducted once in 4 to 7 years (or even longer), aimed at controlling weed or pest infestation, or mixing organic amendments in the soil (Stavi et al. 2011). Other types of moderate tillage include methods that are limited to the shallowest depth of cultivation-such as "shallow tillage," which is common in drylands and Mediterranean regions (Stavi et al. 2015) — or those which shake the soil profile to a certain depth but prevent the turnover and mixing of soil layers (e.g., paraplowing, subsoiling) (Franzluebbers et al. 2007). Despite these features of moderate tillage methods, their effect on the soil water status seems to be site-specific [2] (Miller et al. 2012). Still, the flexibility of these methods provides them with high effectiveness in weed [3] (Gruber and Claupein 2009) and pest control [3] (Kettler et al. 2000). The moderate tillage intensity allows for moderate rates of soil physical quality [2], soil erosion control [2], carbon sequestration [2] (Kettler et al. 2000; Stavi et al. 2011), environmental pollution control [2], and greenhouse gas refuse [2]. The combination of advantages of both of the conventional tillage and no-till methods and, particularly, the comparatively smaller competition by weeds and the lower pressures imposed by pests, together with the moderate adverse impact on soil functions, allows the increase of crop yields [3] (Kettler et al. 2000; Peigné et al. 2007; Ji et al. 2015).

\section{Crop residue management}

After crop harvest, collection of crop residue from the ground surface has been a common practice, implemented for the provision of feed for livestock or feedstock for the emerging bio-energy sector. Another relevant practice is the on-site grazing of crop residue by livestock animals, with the consequent effects on the soil physical and bio-chemical features through trampling action and the excretion of feces and urine. Crop residue management effects on soil functions and ecosystem services are presented in Fig. 3.

The entire removal of crop residue is widely acknowledged to reduce soil moisture content due to the decreased shading of the ground surface, increased evaporation rates, and lower

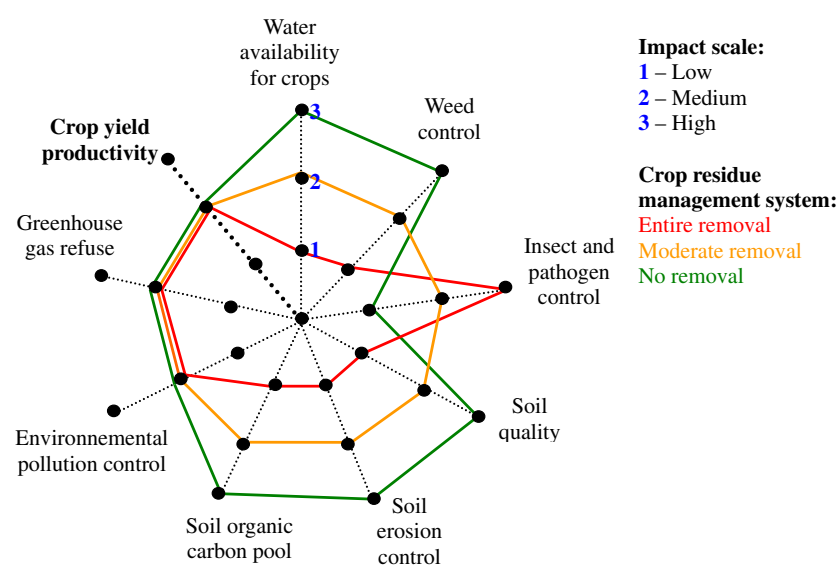

Fig. 3 Spider chart of crop residue management's impact on soil functions and ecosystem services. Impacts are separately presented for the three levels of intensity of crop residue removal, including entire removal, moderate removal, and no removal. The major soil functions and ecosystem services are graded for each of the residue removal intensities according to the scale of the following: 1 for low score, 2 for moderate score, and 3 for high score

availability of water for crops [1] (van Donk et al. 2012; IARI 2012). Nevertheless, the ground surface exposure has been reported to increase soil temperature during the early growing season, increasing weed infestation [1] (Sarajuoghi et al. 2012). Still, the absence of crop residue negates potential habitats for pests, decreasing their density and activity [3] (Cork et al. 2005; IARI 2012). However, the residue removal lowers the protection of the ground surface from the raindrop splash impact and reduces the input of organic matter into the soil, lessening the overall soil quality [1], augmenting erosional processes [1] (Lal and Pimentel 2009), and shrinking stocks of organic carbon in soil [1] (Lal and Pimentel 2009; Stavi and Argaman 2014). Yet, the entire removal of crop residue has no clear-cut impact on environmental quality [2] and greenhouse gas refuse [2] (Dendooven et al. 2012). Nevertheless, in the long run, the entire removal of crop residue can negate maximal productivity of crop yields [2] (van Donk et al. 2012; Ji et al. 2015).

The on-site, entire retention (no removal) of crop residue after harvest has been perceived as an important component of conservation agriculture. It was widely reported that this practice decreases soil-water evaporation loss, augmenting water availability for crops [3] (Govaerts et al. 2007; van Donk et al. 2012). Additionally, the shading effect provided by the crop residue prevents weed germination [3] (Sarajuoghi et al. 2012). At the same time, it also provides habitats for pests, exacerbating risk of their infestation [1] (Cork et al. 2005; Govaerts et al. 2007; IARI 2012). Still, the residue cover protects the ground surface and provides organic materials for the soil, improving overall soil quality [3], efficiently controlling soil erosion [3] (Lal and Pimentel 2009), and augmenting soil organic carbon stock [3] (Dendooven et al. 2012). The entire retention of crop residue has no explicit impact on 
environmental quality [2] (LeBlanc et al. 2011), greenhouse gas refuse [2] (Dendooven et al. 2012), and crop productivity [2] (LeBlanc et al. 2011; New Hampshire Department of Agriculture, Markets, and Food 2011; Miller et al. 2012).

Moderate removal of crop residue is aimed at using some of the organic remains for off-site utilizations, while on site using a certain part of the residues as a cover of the ground surface. It seems that the effects of moderate removal of crop residue on each of the services of water availability for crops, weed control, insect and pathogen control, overall soil quality, soil erosion control, soil organic carbon pool, environmental pollution control, greenhouse gas refuse, and crop yield productivity are site-specific and case-dependant [therefore, a rank of 2 is assigned for each of these services] (Graham et al. 2007; Hatfield et al. 2007; Varvel et al. 2008; Miller et al. 2012; Sarajuoghi et al. 2012; Barsotti et al. 2013; Kirkegaard et al. 2014; Stavi et al. 2015). Regardless, it seems that the overall impact on agroecosystem functioning is utterly determined by the rate of residue retention. Moreover, it seems that critical thresholds of residue retention rate should be determined on a site-dependent basis and taking into account the prevailing climatic, lithologic, topographic, and pedogenic conditions, as well as the cropping history and agrotechnical characteristics (Kirkegaard et al. 2014). Also, it seems that means of residue removal, i.e., whether it is collected by agricultural machineries or consumed by livestock animals (as a part of mixed agro-pastoral farming), is an important determinant of impact on the geo-ecosystem. For example, recent studies highlighted no adverse effect, or even positive effect, of moderate grazing of crop residue on weed control (Barsotti et al. 2013), as well as on the soil's nutrient status (Hatfield et al. 2007), physical quality, hydraulic characteristics, and organic carbon pool (Stavi et al. 2015). These impacts are attributed to the combined effect of the trampling action that breaks down the mechanical crust which covers the ground surface, feces excretion that provides the soil with a more labile form of organic carbon, and the mixing of stubble residue and feces in soil (Stavi et al. 2016). Incorporating these effects into the conceptual model would be expected to considerably increase the overall score of moderate removal of crop residue (and consequently, improving the score of moderate-intensity and integrated agricultural systems). Nevertheless, these effects were not synthesized into the conceptual model since this study was focused on the most widely acknowledged impacts.

\section{Nutrient management}

The provision of soil with nutrients may be implemented before or during the seeding/planting of crops, as well as during the growing season, and is aimed at replenishing soil elements and providing crops with their nutritive needs. Nutrient management effects on soil functions and ecosystem services are presented in Fig. 4.

Chemical nutrient management involves no organic additives that tend to increase macro-aggregation processes and water holding capacity and, therefore, has the least positive impact on the soil-water and its availability for crops [1] (Sene and Badiane 2005; Blanco-Canqui et al. 2015; Wu and Ma 2015). This management has no clear effect on weed infestation [2]. At the same time, due to the decreased soil health, it may increase infestation of soil pathogens [1] (Horrigan et al. 2002). Also, the no replenishment of organic matter stocks decreases the overall soil quality [1] (Chivenge et al. 2011), erosion control [1] (Miller et al. 2012; Lal 2015), and soil organic carbon pools [1] (Chivenge et al. 2011). In addition, the chemical soil additives, such as nitrates, are highly prone to spatial redistribution through surface processes, as well as to deep percolation, risking quality of surface and belowground water sources [1] (Horrigan et al. 2002; Miller et al. 2012; Wu and Ma 2015). Additionally, the greenhouse gas footprint of chemical fertilizer is incredibly high, with considerable emissions of carbon dioxide and nitrous oxide both offfarm (during geological extraction and industrial manufacturing) and on-farm [1] (Ho 2011; Zhang et al. 2012; Wu and Ma 2015). Despite being effective in increasing yields in the short run, chemical nutrient management could impede crop productivity in the long run [2] (e.g., Choudhary et al. 2013; Wu and Ma 2015).

Among the organic soil-nutrient additives, livestock manures are predominant. The organic additives employed in organic nutrient management regimes tend to increase the soil macro-aggregate formation, augmenting water availability for crops [3] (Sene and Badiane 2005; Blanco-Canqui et al. 2015). However, plant residue-based amendments that are

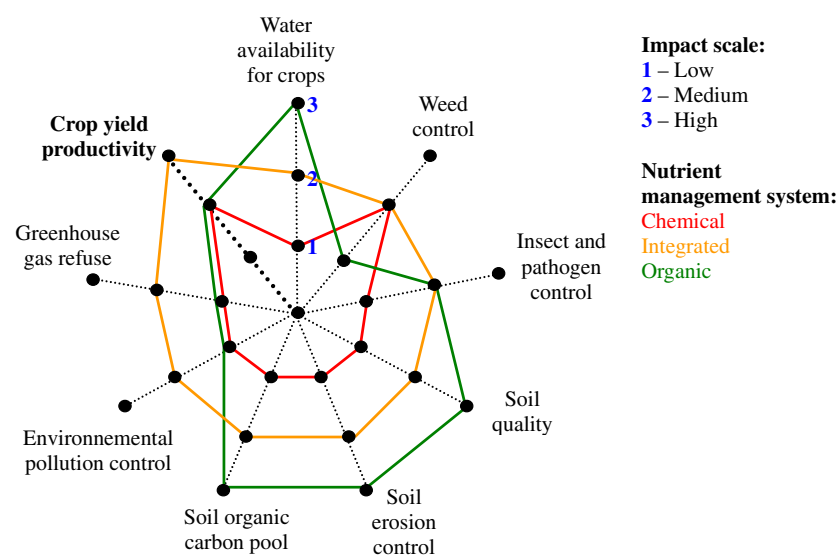

Fig. 4 Spider chart of nutrient management's impact on soil functions and ecosystem services. Impacts are separately presented for the three levels of intensity of nutrient management, including chemical, integrated, and organic. The major soil functions and ecosystem services are graded for each of the nutrient management intensities according to the scale of the following: 1 for low score, 2 for moderate score, and 3 for high score 
handled incorrectly might contain vital seed banks, increasing risk of weed infestation [1] (Dastgheib 1989; Larney and Blackshaw 2003). Regardless, due to the sustaining of soil microbial activity, the organic additives are likely to increase soil health, reducing infestation of soil-borne pathogens (Horrigan et al. 2002). Still, organic additives that are incorrectly processed may increase the risk of pathogen that could infest subsequent crops [2] (Erickson et al. 2014; Millner et al. 2014). Yet, these additives help to increase the overall soil quality [3] (Chivenge et al. 2011), erosion control [3] (Miller et al. 2012; Lal 2015), and organic carbon stocks [3] (Chivenge et al. 2011; Zhang et al. 2012). However, application of organic additives, such as livestock manure, can increase the risk of contamination of above-ground and belowground water sources, jeopardizing environmental quality [1] (Horrigan et al. 2002; Flores et al. 2012; Tuomisto et al. 2012). Also, the production (in dairy and poultry farms, composting facilities, etc.) and on-farm use of these additives are characterized with high greenhouse gas emissions [1] (Tuomisto et al. 2012; Fukumoto et al. 2015; Owen and Silver 2015). Ultimately, the relatively slower turnover of organic additives compared to chemical ones makes their nutrient content to be of moderate availability in the short run, restraining the rate of crop yield productivity [2] (Magen 2008; Chivenge et al. 2011; New Hampshire Department of Agriculture, Markets, and Food 2011).

Integrated nutrient management allows the combined utilization of chemical and organic soil additives. The embedded flexibility in integrated nutrient management enables the adoption of a range of strategies and taking ad hoc decisions according to the dynamic circumstances, with the ultimate goal of best fitting soil nutrient status according to crop needs (Chivenge et al. 2011). The combining of organic additives enables the moderate formation of soil macro-aggregate, with the resultant moderate availability of water for crops [2] (Sene and Badiane 2005; Wu and Ma 2015). The impacts of integrated nutrient management on infestation of weeds, as well as insects and pathogens, are not direct and generally are case-dependant and site-specific [2]. At the same time, integrated nutrient management has a moderate impact on overall soil quality [2] (Chivenge et al. 2011), soil erosion control [2] (Miller et al. 2012), and soil organic carbon pool [2] (Chivenge et al. 2011; Zhang et al. 2012). The integrated nutrient management's relatively high nutrient-use efficiency by crops moderates their leakage to the environment [2] (Miller et al. 2012; Wu and Ma 2015) and mitigates greenhouse gas emissions [2] ( $\mathrm{Wu}$ and $\mathrm{Ma}$ 2015). The combined effect of these services, and particularly the moderate impact on soil functions, results in the formation of a supportive habitat for sustaining crop productivity [3] (Chivenge et al. 2011; Choudhary et al. 2013; Wu and Ma 2015).

\section{Pest management}

Pest management has been developed since the onset of agriculture and the domestication of plants. Pest management effects on soil functions and ecosystem services are presented in Fig. 5. Overall, compared to any of the above-discussed core farming practices, pest control is not generally perceived to directly nor considerably impact many of the related soil functions and ecosystem services. Therefore, only scant research has been implemented on some of these services, including soil quality, soil erosion control, soil organic carbon pool, and greenhouse gas emissions. Thus, in this section, pest control was generally (though not exclusively) assumed to have indirect effect, no clear effect, or irrelevance for each of these, with the consequent scoring of 2 .

Chemical pest management includes the use of herbicides, insecticides, fungicides, nematicides, etc. Overall, the application of these chemicals to croplands has an indirect effect on water availability for crops due to the effective elimination of competitive weeds [3] (Washington State University Cooperative Extension 2003; Khanh et al. 2007). Yet, regarding the very specific target of controlling weed and pest infestation, many studies have reported the possible adaptation in community structure and/or the development of resistance mechanisms, resulting in decreased effectiveness of chemical control of weeds [2] (Horrigan et al. 2002), insects, and pathogens [2] over time (Horrigan et al. 2002; Miller et al. 2012). Chemical pest management has no clear effect for either overall soil quality [2] or soil erosion control [2]. At the same time, the negation of soil detritivores decreases the cycling of plant residues, with the consequent smaller organic carbon pool in soil [1] (Wang et al. 2001; Souza et al. 2012). Also, chemical pest management has the potential to pollute on-site and offsite water bodies and contaminate soil and air resources,

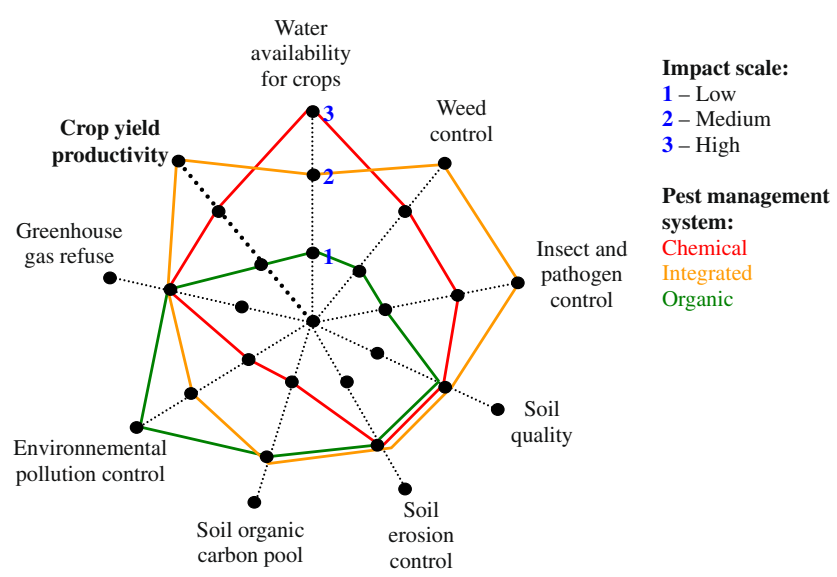

Fig. 5 Spider chart of pest management's impact on soil functions and ecosystem services. Impacts are separately presented for the three levels of intensity of pest management, including chemical, integrated, and organic. The major soil functions and ecosystem services are graded for each of the pest management intensities according to the scale of the following: 1 for low score, 2 for moderate score, and 3 for high score 
highly risking environmental quality [1] (Horrigan et al. 2002; LeBlanc et al. 2011). Still, chemical pest management has no clear-cut effect on greenhouse gas emissions [2] (West and Marland 2002). Over the long term, the impact of chemical pest management on crop yield productivity is case-dependant and varies highly in space and time [2] (Way and van Emden 2000; Rodríguez and Niemeyer 2005; Hassanali et al. 2008).

Organic pest management includes the use of natural enemies for pest control. For example, carnivore insects and acari which attack pests at different phonological stages, as eggs, larva, or mature individuals. Regardless, organic methods have been supported by tillage activities - both before and during the growing season-particularly aimed not only at controlling weed infestation, but also at controlling a range of other pests. Yet, the use of (inter-row) tillage during the growing season is only possible for row crops, where plants are planted on linear soil ridges or beds. Pest traps have also been used, attracting insects and neutralizing their potential damage. One way or another, the potentially greater risk of weed infestation might decrease water availability for crops [1]. As stated, organic pest management may increase infestation by weeds [1] (Lazauskas and Pilipavicius 2004; Gruber and Claupein 2009), as well as by insects and pathogens [1] (Hansen et al. 2008; McPherson et al. 2008). Regardless, organic pest management has no direct effect on overall soil quality [2], soil erosion control [2], and soil organic carbon pools [2]. However, it is defined as having a comparatively low impact on environmental quality [3] (van Bruggena and Termorshuizen 2003; Birkhofer et al. 2008). Organic methods have no direct effect on greenhouse gas emissions [2]. Despite being case-dependant, risk of crop failure due to pest or weed infestation in organic pest management is comparatively high [1] (Ngouajio et al. 2003; Birkhofer et al. 2008; Pretty and Bharucha 2015).

Integrated pest management is defined by the simultaneous and flexible use of a range of means, including tillage (harrowing), mechanical (installing insect traps), and cultural (variety selection, fallowing, crop rotation, cover cropping, etc.) measures. Simultaneously, case-dependant means for crop protection can be applied, including biological pest control, with the possible application of some (relatively lowtoxicity) chemicals (Pretty and Bharucha 2015) or "bio-pesticides." Despite having no direct effect on water availability for crops [2], the integrated pest management effectively controls weeds [3] (Smith and Menalled 2012; Harker and O'Donovan 2013) and pathogens [3] (Reddy 2011; Pretty and Bharucha 2015). At the same time, the integrated pest management has no clear-cut effect on overall soil quality [2], soil erosion control [2], soil organic carbon pool [2], environmental quality [2] (Smith and Menalled 2012; Harker and O'Donovan 2013), or greenhouse gas emissions [2]. Still, the decreased competition by weeds and the lower stress by insects and pathogens result in the comparatively greater quality and quantity of crop yields [3] (Rodríguez and Niemeyer 2005; Hassanali et al. 2008).

\section{Data integration and general discussion}

Scores for each of the four farming practices and three intensities (per farming practice) and according to the nine soil functions and ecosystem services (per combination of farming practice and function/service) were normalized. Then, averaging the normalized scores of the four farming practices according to agricultural system intensity and separately for each of the nine functions/services yielded an inclusive score per agricultural system per function/service (Fig. 6). An overall scoring framework - for each of the conventional, integrated, and conservation agricultural systems - generated a single inclusive score for all of the studied functions/services (excluding crop yield productivity) (Table 1). The overall scoring (out of a potential maximum of $100 \%$ ), excluding crop yield productivity, showed the highest score for conservation systems, which was only $5 \%$ higher than that of integrated systems, but $38 \%$ higher than that of conventional systems. The crop yield productivity score (also, out of a potential maximum of $100 \%$ ) was the highest for integrated systems, which was $25 \%$ higher than that of conventional systems and $43 \%$ higher than that of conservation systems. It is acknowledged that site-specific and local conditions could have slightly changed these scores. Nevertheless, despite occasional exceptions, the general trends of scoring according to which (a) agro-environmental sustainability follows the trend of conservation systems $>$ integrated systems $>$ conventional systems and (b) crop yield productivity follows the trend of integrated systems $>$ conventional systems $>$ conservation systems would have remained the same.

Most of the soil functions and ecosystem services - including water availability for crops, weed control, insect and pathogen control, soil quality, soil erosion control, and soil organic carbon pool - directly impact agricultural productivity. At the same time, the services of environmental pollution control and greenhouse gas refuse have no direct, on-farm, impact. Yet, numerous studies have proven the positive relations between environmental quality and agricultural productivity (e.g., Agrawal 2005), as well as between carbon dioxide's atmospheric concentrations and agronomic sustainability (e.g., Vadez et al. 2012). One way or another, besides the environmental impact of agricultural activities, an opposite impact, namely, the effects of environmental conditions on agronomic features, should also be considered by farmers. Regardless, since the early twenty-first century, different schemes to compensate land managers have been proposed, providing incentives for implementing less environmentally harmful farming practices. Among these schemes, the "Farm Bill" practiced in the USA (Reimer 2015) encompasses a good example of how 
Fig. 6 Inclusive scores per agricultural system per soil function/ecosystem service. These scores are the average of the scores presented in Figs. 2, 3, 4 , and 5. Line for each function/ service represents the range between 0 (the web center) and $100 \%$ (outer bullets)

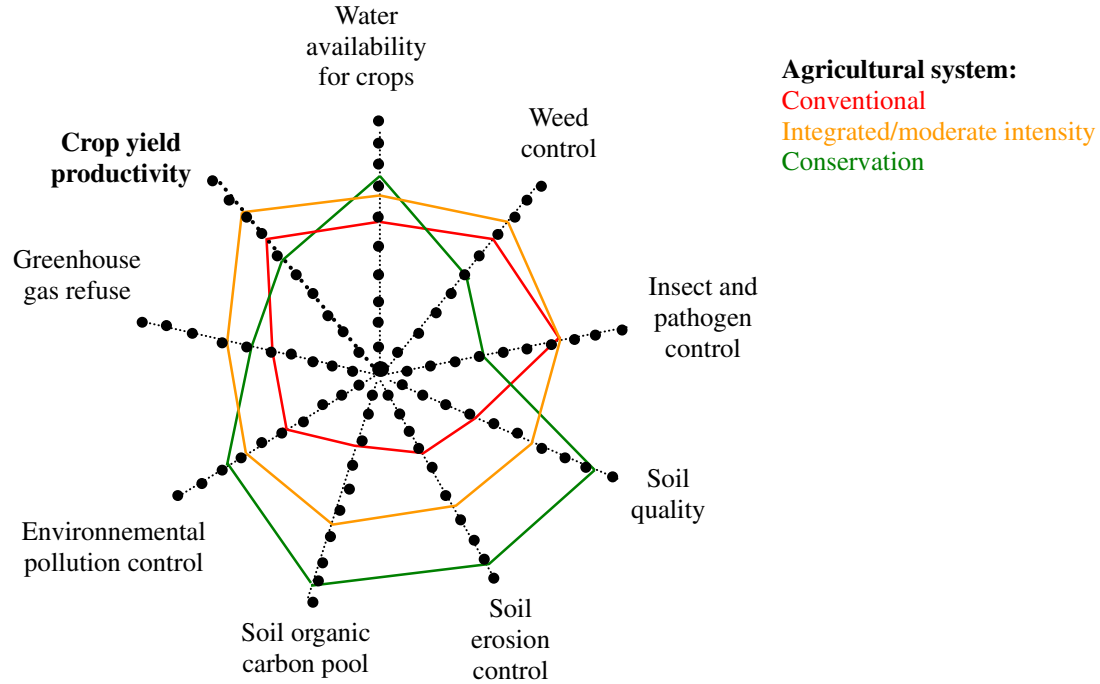

to encourage farmers to sustain a range of ecosystem services in order to promote food security over the long term.

Irrespective of these schemes, the evaluation of direct economic costs (of inputs such as fuel, fertilizers, livestock manure and compost, pesticides, and organic means of pest control, as well as the purchase and maintenance of agricultural machinery) and benefits (from selling the agricultural products) of each of the conventional, integrated, and conservation agricultural systems is rather complicated as they are simultaneously affected by a wide range of local, national, and global factors. In addition to these direct costs and benefits, the indirect costs due to land degradation and environmental deterioration processes should also be considered. Yet, in terms of input-use efficiency, it is generally agreed that conventional systems are the least efficient (Duru et al. 2015), because of the decrease on their economic return over the long term. At the same time, as revealed by this study, if crop yield productivity indicates an economic return, then integrated systems seem to best function in this aspect.

The novel approach of the conceptual model_-stemming from the inclusive assessment and comparisons among the conventional, integrated, and conservation agricultural

Table 1 Scoring (of a potential maximum of $100 \%$ ) according to agricultural system

$\begin{array}{lll}\text { Conventional } & \text { Integrated/ } & \text { Conservation } \\ \text { systems } & \begin{array}{l}\text { moderate } \\ \text { intensity }\end{array} & \text { systems } \\ & \text { systems } & \\ & \end{array}$

\begin{tabular}{lccc}
\hline $\begin{array}{l}\text { Overall agro- } \\
\text { environmental score } \\
\text { (excluding crop yield }\end{array}$ & 52.1 & 68.8 & 71.9 \\
$\begin{array}{l}\text { productivity, \%) } \\
\begin{array}{l}\text { Crop yield productivity } \\
\text { score (\%) }\end{array}\end{array}$ & 66.7 & 83.3 & 58.3 \\
\hline
\end{tabular}

systems — makes it effective in comprehensively studying their agro-environmental impacts. Specifically, it shows that compared with both of the conventional and conservation agricultural systems, the integrated and moderate-intensity agricultural systems are preferable in terms of crop yield productivity, along with the adequate sustaining of environmental quality and health. As such, in the long run, integrated and moderate-intensity farming systems seem to cope comparatively better with global food security.

\section{Conclusions}

Each of the two extremes of conventional and conservation agricultural systems not only bears considerable agroenvironmental advantages, but also faces substantial agronomic challenges. Despite the developed conceptual model having some limitations, its novelty allows for comparison between these two extremes and between each of them and the moderate-intensity and integrated farming systems. As shown in this review study, the moderate-intensity and integrated farming systems are expected to provide satisfactory conditions for crop production, while adequately sustaining environmental quality and health. The findings generated from this study bear implications for both farmers and policy makers and equip them with environmentally sound solutions for sustainable land management. It is expected that due to the continuously growing human population, coupled with the anticipated climatic change and shrinking of natural resources, the features of moderate-intensity and integrated farming systems make them attractive for expansion in the near future.

\footnotetext{
Acknowledgments The authors are grateful to five anonymous reviewers, whose comments enabled the considerable improvement of the paper's original version.
} 


\section{References}

Abdin OA, Zhou XM, Cloutier D, Coulman DC, Faris MA, Smith DL (2000) Cover crops and interrow tillage for weed control in short season maize (Zea mays). Eur J Agron 12:93-102. doi:10.1016/ S1161-0301(99)00049-0

Agrawal M (2005) Effects of air pollution on agriculture: an issue of national concern. Natl Acad Sci Lett 28:93-106

Alexander P, Rounsevell MDA, Dislich C, Dodson JR, Engstrom K, Moran D (2015) Drivers for global agricultural land use change: the nexus of diet, population, yield and bioenergy. Glob Environ Chang 35:138-147. doi:10.1016/j.gloenvcha.2015.08.011

Barsotti JL, Sainju UM, Lenssen AW, Montagne C, Hatfield PG (2013) Crop yields and soil organic matter responses to sheep grazing in US northern Great Plains. Soil Till Res 134:133-141. doi:10.1016/j.still. 2013.07.015

Birkhofer K, Bezemer TM, Bloem J, Bonkowski M, Christensen S, Dubois D, Ekelund F, Fliessbach A, Gunst L, Hedlund K, Mader P, Mikola J, Robin C, Setala H, Tatin-Froux F, Van der Putten WH, Scheu S (2008) Long-term organic farming fosters below and aboveground biota: implications for soil quality, biological control and productivity. Soil Biol Biochem 40:2297-2308. doi:10.1016/j. soilbio.2008.05.007

Blanco-Canqui H, Hergert GW, Nielsen RA (2015) Cattle manure application reduces soil compactibility and increases water retention after 71 years. Soil Sci Soc Am J 79:212-223. doi:10.2136/sssaj2014.06. 0252

Cabanillas HE, Bradford JM, Smart JR (1999) Effect of tillage system, soil type, crop stand, and crop sequence on reniform nematodes after harvest. Nematropica 29:137-146

Chen XP, Cui ZL, Vitousek PM, Cassman KG, Matson PA, Bai JS, Meng QF, Hou P, Yue SC, Römheld V, Zhang FS (2011) Integrated soilcrop system management for food security. PNAS 108:6399-6404

Chivenge P, Vanlauwe B, Six J (2011) Does the combined application of organic and mineral nutrient sources influence maize productivity? A meta-analysis. Plant Soil 342:1-30. doi:10.1007/s11104-0100626-5

Choudhary AK, Thakur SK, Suri VK (2013) Technology transfer model on integrated nutrient management technology for sustainable crop production in high-value cash crops and vegetables in northwestern Himalayas. Commun Soil Sci Plant 44:1684-1699. doi:10.1080/ 00103624.2013 .783058

Cork A, Alam SN, Rouf FMA, Talekar NS (2005) Development of mass trapping technique for control of brinjal shoot and fruit borer, Leucinodes orbonalis (Lepidoptera: Pyralidae). B Entomol Res 95: 589-596. doi:10.1079/BER2005389

Dastgheib F (1989) Relative importance of crop seed, manure and irrigation water as source of weed infestation. Weed Res 29:113-116. doi: 10.1111/j.1365-3180.1989.tb00848.x

Dendooven L, Patiño-Zúñiga L, Verhulst N, Luna-Guido M, Marsch R, Govaerts B (2012) Global warming potential of agricultural systems with contrasting tillage and residue management in the central highlands of Mexico. Agric Ecosyst Environ 152:50-58. doi:10.1016/j. agee.2012.02.010

Duru M, Therond O, Martin G, Martin-Clouaire R, Magne MA, Justes E, Journet EP, Aubertot JN, Savary S, Bergez JE, Sarthou JP (2015) How to implement biodiversity-based agriculture to enhance ecosystem services: a review. Agron Sustain Dev 35:1259-1281. doi: 10.1007/s13593-015-0306-1

Erickson MC, Liao J, Jiang XP, Doyle MP (2014) Inactivation of pathogens during aerobic composting of fresh and aged dairy manure and different carbon amendments. J Food Prot 77:1911-1918. doi:10. 4315/0362-028X.JFP-14-194

Flores H, Arumi JL, Rivera D, Lagos LO (2012) A simple method to identify areas of environmental risk due to manure application.
Environ Monit Assess 184:3915-3928. doi:10.1007/s10661-0112233-1

Fukumoto Y, Suzuki K, Waki M, Yasuda T (2015) Mitigation option of greenhouse gas emissions from livestock manure composting. JARQ-Jpn Agr Res Q 49:307-312

Franzluebbers AJ, Schomberg HH, Endale DM (2007) Surface-soil responses to paraplowing of long-term no-tillage cropland in the Southern Piedmont USA. Soil Till Res 96:303-315. doi:10.1016/j. still.2007.07.001

Govaerts B, Fuentes M, Mezzalama M, Nicol JM, Deckers J, Etchevers JD, Figueroa-Sandoval B, Sayre KD (2007) Infiltration, soil moisture, root rot and nematode populations after 12 years of different tillage, residue and crop rotation managements. Soil Till Res 94: 209-219. doi:10.1016/j.still.2006.07.013

Graham RL, Nelson R, Sheehan J, Perlack RD, Wright LL (2007) Current and potential U.S. corn stover supplies. Agron J 99:1-11. doi:10. 2134/agronj2005.0222

Gruber S, Claupein W (2009) Effect of tillage intensity on weed infestation in organic farming. Soil Till Res 105:104-111. doi:10.1016/j. still.2009.06.001

Hansen LM, Lorentsen L, Boelt B (2008) How to reduce the incidence of black bean aphids (Aphis fabae Scop.) attacking organic growing field beans (Vicia faba L.) by growing partially resistant bean varieties and by intercropping field beans with cereals. Acta Agr Scand B-S P 58:359-364. doi:10.1080/09064710701788844

Harker KN, O'Donovan JT (2013) Recent weed control, weed management, and integrated weed management. Weed Technol 27:1-11. doi:10.1614/WT-D-12-00109.1

Harker KN, O'Donovan JT, Turkington TK, Blackshaw RE, Johnson EN, Brandt SA, Kutcher HR, Clayton GW (2013) Weed interference impacts and yield recovery after four years of variable crop inputs in no-till barley and canola. Weed Technol 27:281-290. doi:10. 1614/WT-D-12-00115.1

Haslmayr HP, Geitner C, Sutor G, Knoll A, Baumgarten A (2016) Soil function evaluation in Austria - development, concepts and examples. Geoderma 264:379-387. doi:10.1016/j.geoderma.2015.09. 023

Hassanali A, Herren H, Khan ZR, Pickett JA, Woodcock CM (2008) Integrated pest management: the push-pull approach for controlling insect pests and weeds of cereals, and its potential for other agricultural systems including animal husbandry. Philos Trans R Soc B 363:611-621. doi:10.1098/rstb.2007.2173

Hatfield PG, Goosey HB, Spezzano TM, Blodget SL, Lenssen AW, Kott RW, Marlow CB (2007) Incorporating sheep into dryland grain production systems III. Impact on changes in soil bulk density and soil nutrient profiles. Small Rumin Res 67:222-231. doi:10.1016/j. smallrumres.2005.10.003

Ho JA (2011) Calculation of the carbon footprint of Ontario wheat. Studies by Undergraduate Researchers at Guelph 4, 49-55

Horrigan L, Lawrence RS, Walker P (2002) How sustainable agriculture can address the environmental and human health harms of industrial agriculture. Environ Health Perspect 110:445-456

Hurni H, Giger M, Liniger H, Studer RM, Messerli P, Portner B, Schwilch G, Wolfgramm B, Breu T (2015) Soils, agriculture and food security: the interplay between ecosystem functioning and human well-being. Curr Opin Environ Sustain 15:25-34. doi:10.1016/ j.cosust.2015.07.009

IARI (2012) Crop residues management with conservation agriculture: potential, constraints and policy needs. Indian Agricultural Research Institute, New Delhi. http://www.iari.res.in/files/Important Publications-2012-13.pdf

Jankielsohn A (2015) The hidden cost of eating meat in South Africa: what every responsible consumer should know. J Agric Environ Ethics 28:1145-1157. doi:10.1007/s10806-015-9581-8

Ji Q, Wang Y, Chen XN, Wang XD (2015) Tillage effects on soil aggregation, organic carbon fractions and grain yield in Eum-Orthic 
Anthrosol of a winter wheat-maize double-cropping system, Northwest China. Soil Use Manag 31:504-514. doi:10.1111/sum. 12213

Kennedy AC, Schillinger WF (2006) Soil quality and water intake in traditional-till vs. no-till paired farms in Washington's Palouse region. Soil Sci Soc Am J 70:940-949. doi:10.2136/sssaj2005.0160

Kettler TA, Lyon DJ, Doran JW, Powers WL, Stroup WW (2000) Soil quality assessment after weed-control tillage in a no-till wheat-fallow cropping system. Soil Sci Soc Am J 64:339-346. doi:10.2136/ sssaj2000.641339x

Khanh TD, Elzaawely AA, Chung IM, Ahn JK, Tawata S, Xuan TD (2007) Role of allelochemicals for weed management in rice. Allelopath J 19:85-95

Kirkegaard JA, Conyers MK, Hunt JR, Kirkby CA, Watt M, Rebetzke GJ (2014) Sense and nonsense in conservation agriculture: principles, pragmatism and productivity in Australian mixed farming systems. Agric Ecosyst Environ 187:133-145. doi:10.1016/j.agee.2013.08. 011

Lal R (2004) Carbon emission from farm operations. Environ Int 30:981990. doi:10.1016/j.envint.2004.03.005

Lal R, Pimentel D (2009) Biofuels: beware crop residues. Science 326: 1345-1346

Lal R (2015) Restoring soil quality to mitigate soil degradation. Sustainability 7:5875-5895. doi:10.3390/su7055875

Larney FJ, Blackshaw RE (2003) Weed seed viability in composted beef cattle feedlot manure. J Environ Qual 32:1105-1113

Lazauskas P, Pilipavicius V (2004) Weed control in organic agriculture by the two layer-plough. Z Pflanzenk Pflanzen 19:573-580

LeBlanc BD, Sheffield RE, Kruse J, Nix KE (2011) Environmental best management practices for agronomic crops, soybeans, cotton, wheat, corn and feed grains. Louisiana State University AgCenter. https:// www.lsuagcenter.com/NR/rdonlyres/3EF63A05-7F99-4D72-84ED1ABBC9628879/84012/pub2807AgronomicCropsBMPLOWRES. pdf

Liu GB (1999) Soil conservation and sustainable agriculture on the Loess Plateau: challenges and prospects. Ambio 28:663-668

Magen H (2008) Balanced crop nutrition: fertilizing for crop and food quality. Turk J Agric For 32:183-193

McLaughlin A, Mineau P (1995) The impact of agricultural practices on biodiversity. Agr Ecosyst Environ 55:201-212. doi:10.1016/01678809(95)00609-V

McPherson RM, Johnson WC, Fonsah EG, Roberts PM (2008) Insect pests and yield potential of vegetable soybean (edamame) produced in Georgia. J Entemol Sci 43:335-240

Miller TP, Peterson JR, Lenhart CF, Nomura Y (2012) The agricultural BMP handbook for Minnesota. Minnesota Department of Agriculture. Minnesota Department of Agriculture, St. Paul, MN

Millner P, Ingram D, Mulbry W, Arikan OA (2014) Pathogen reduction in minimally managed composting of bovine manure. Waste Manag 34:1992-1999. doi:10.1016/j.wasman.2014.07.021

Ngouajio M, McGiffen ME, Hutchinson CM (2003) Effect of cover crop and management system on weed populations in lettuce. Crop Prot 22:57-64. doi:10.1016/S0261-2194(02)00111-4

New Hampshire Department of Agriculture, Markets, and Food (2011) Manual of best management practices (BMPs) for agriculture in New Hampshire. Best management practices for the handling of agricultural compost, fertilizer, and manure. Concord, $\mathrm{NH}$

Nixon L (2009) No-till benefits: we no-tillers really make our money in the normal years. Farm and Home Research. http://www.sdwheat. org/wp-content/uploads/2014/11/notill.pdf

Owen JJ, Silver WL (2015) Greenhouse gas emissions from dairy manure management: a review of field-based studies. Glob Chang Biol 21: 550-565. doi:10.1111/gcb. 12687

Peigné J, Ball BC, Roger-Estrade J, David C (2007) Is conservation tillage suitable for organic farming? A review. Soil Use Manag 23: 129-144. doi:10.1111/j.1475-2743.2006.00082.x
Pretty J, Bharucha ZP (2015) Integrated pest management for sustainable intensification of agriculture in Asia and Africa. Insects 6:152-182. doi:10.3390/insects6010152

Reimer A (2015) Ecological modernization in US agri-environmental programs: trends in the 2014 Farm Bill. Land Use Policy 47:209 217. doi:10.1016/j.landusepol.2015.04.013

Reddy GVP (2011) Comparative effect of integrated pest management and farmers' standard pest control practice for managing insect pests on cabbage (Brassica spp.). Pest Manag Sci 67:980-985. doi:10. $1002 /$ ps. 2142

Rodríguez LC, Niemeyer HM (2005) Integrated pest management, semiochemicals and microbial pest-controlagents in Latin American agriculture. Crop Prot 24:615-623. doi:10.1016/j.cropro.2004.11. 006

Sarajuoghi M, Mafakheri S, Rostami R, Shahbazi S (2012) Rapeseed residue management for weed control and corn production. Indian J Sci Technol 5:2587-2589

Schneider UA, Smith P (2009) Energy intensities and greenhouse gas emission mitigation in global agriculture. Energy Effic 2:195-206. doi:10.1007/s12053-008-9035-5

Sene N, Badiane AN (2005) Optimization of water and nutrient use by maize and peanut in rotation based on organic and rock phosphate soil amendment. In: Nutrient and water management practices for increasing crop production in rainfed arid/semi-arid areas. Proceedings of a coordinated research project. International Atomic Energy Agency, Vienna. p. 197-208. http://www-pub.iaea. org/MTCD/publications/PDF/te_1468_web.pdf

Smith RG, Menalled FD (2012) Integrated strategies for managing agricultural weeds: making cropping systems less susceptible to weed colonization and establishment. Montana State University Extension

Souza CR, Sarmento RA, Venzon M, Barros EC, dos Santos GR, Chaves CC (2012) Impact of insecticides on non-target arthropods in watermelon crop. Semin Cienc Agrar 33:1789-1801. doi:10.5433/16790359.2012v33n5p1789

Stavi I, Lal R, Owens LB (2011) On-farm effects of no-till versus occasional tillage on soil quality and crop yields in eastern Ohio. Agron Sustain Dev 31:475-482. doi:10.1007/s13593-011-0006-4

Stavi I, Argaman E (2014) No-till systems: gains and drawbacks for carbon sequestration, ecosystem services and environmental health. Carbon Manag 5:123-125. doi:10.1080/17583004.2014.912828

Stavi I, Barkai D, Islam KR, Zaady E (2015) No adverse effect of moderate stubble grazing on soil quality and organic carbon pool in dryland wheat agro-ecosystems. Agron Sustain Dev 35:1117-1125. doi:10.1007/s13593-015-0299-9

Stavi I, Argaman E, Zaady E (2016) Positive impact of moderate stubble grazing on soil quality and organic carbon pool in dryland wheat agro-pastoral systems. Catena. (in press). doi: 10.1016/j.catena. 2016.02.004

TerAvest D, Carpenter-Boggs L, Thierfelder C, Reganold JP (2015) Crop production and soil water management in conservation agriculture, no-till, and conventional tillage systems in Malawi. Agr Ecosyst Environ 212:285-296. doi:10.1016/j. agee.2015.07.011

Tilman D, Socolow R, Foley JA, Hill J, Larson E, Lynd L, Pacala S, Reilly J, Searchinger T, Somerville C, Williams R (2009) Beneficial biofuels - the food, energy, and environment trilemma. Science 325:270-271

Tuomisto HL, Hodge ID, Riordan P, Macdonald DW (2012) Does organic farming reduce environmental impacts? - a metaanalysis of European research. J Environ Manag 112:309320. doi:10.1016/j.jenvman.2012.08.018

Vetsch JA, Randall GW, Lamb JA (2007) Corn and soybean production as affected by tillage systems. Agron J 99:952-959. doi:10.2134/ agronj2006.0149 
Wienhold BJ, Weil RR (2006) Preserving soil and crop resources by increasing cropping intensity and decreasing tillage. Renew Agr Food Syst 21:1-2. doi:10.1079/RAF2005120

Vadez V, Berger JD, Warkentin T, Asseng S, Ratnakumar P, Rao KPC, Gaur PM, Munier-Jolain N, Larmure A, Voisin AS, Sharma HC, Pande S, Sharma M, Krishnamurthy L, Zaman MA (2012) Adaptation of grain legumes to climate change: a review. Agron Sustain Dev 32:31-44. doi:10.1007/s13593-011-0020-6

van Bruggena AHC, Termorshuizen AJ (2003) Integrated approaches to root disease management in organic farming systems. Australas Plant Pathol 32:141-156. doi:10.1071/AP03029

van Donk SJ, Shaver TM, Petersen JL, Davison DR (2012) Effects of crop residue removal on soil water content and yield of deficitirrigated soybean. T ASABE 55:149-157

Varvel GE, Vogel KP, Mitchell RB, Follett RF, Kimble JM (2008) Comparison of corn and switchgrass on marginal soils for bioenergy. Biomass Bioenergy 32:18-21. doi:10.1016/j.biombioe. 2007.07.003

Vyn TJ, West T, Roth J, Kovacs P, Ciampitti I, Xia Y (2013) Corn and soybean access to soil water in "drought years": no-till and crop management experiences. Purdue University

Wang Y, Crocker RL, Wilson LT, Smart G, Wei X, Nailon WT, Cobb PP (2001) Effect of nematode and fungal treatments on nontarget turfgrass-inhabiting arthropod and nematode populations. Environ Entomol 30:196-203. doi:10.1603/0046-225X-30.2.196
Washington State University Cooperative Extension (2003) Water conservation, weed control go hand in hand. Drought Advisory, WA. http://cru.cahe.wsu.edu/CEPublications/em4856/em4856.pdf

Way MJ, van Emden HF (2000) Integrated pest management in practice-pathways towards successful application. Crop Prot 19:81103

West TO, Marland G (2002) A synthesis of carbon sequestration, carbon emissions, and net carbon flux in agriculture: comparing tillage practices in the United States. Agric Ecosyst Environ 91:217-232

Williams A, Hedlund K (2014) Indicators and trade-offs of ecosystem services in agricultural soils along a landscape heterogeneity gradient. App Soil Ecol 77:1-8. doi:10.1016/j.apsoil.2014.01.001

$\mathrm{Wu} \mathrm{W}, \mathrm{Ma} B$ (2015) Integrated nutrient management (INM) for sustaining crop productivity and reducing environmental impact: a review. Sci Total Environ 512-513:415-427. doi:10.1016/j.scitotenv.2014. 12.101

Zhang F, Cui Z, Chen X, Ju X, Shen J, Chen Q, Liu X, Zhang W, Mi G, Fan M, Jiang R (2012) Integrated nutrient management for food security and environmental quality in China. Adv Agron 116:140. doi:10.1016/B978-0-12-394277-7.00001-4

Zdruli P, Calabrese J, Ladisa G, Otekhile A (2014) Impacts of land cover change on soil quality of manmade soils cultivated with table grapes in the Apulia Region of south-eastern Italy. Catena 121:13-21. doi: 10.1016/j.catena.2014.04.015 